\title{
Proteasome inhibitor inhibits proliferation and induces apoptosis in renal interstitial fibroblasts
}

\author{
Bingbing Zhu, ${ }^{1,2}$, Yuanmeng Jin ${ }^{1}$, Lin Han ${ }^{1}$, Hui Chen ${ }^{1}$, Fang Zhong ${ }^{1}$, \\ Weiming Wang ${ }^{1}$, Nan Chen ${ }^{1}$ \\ ${ }^{1}$ Department of Nephrology, Ruijin Hospital, Shanghai Jiao Tong University, Shanghai, 200025, P.R. China \\ ${ }^{2}$ Department of Nephrology, Putuo Hospital Affiliated with Shanghai University of Traditional Chinese Medicine, \\ Shanghai, 200062, P.R. China
}

Correspondence: Weiming Wang, e-mail: wweiming@medmail.com.cn

\begin{abstract}
:
Background: The ubiquitin proteasome pathway plays a pivotal role in controlling cell proliferation, apoptosis and differentiation in a variety of normal and tumor cells. This study aimed to investigate the role of a proteasome inhibitor on proliferation, apoptosis and related proteins in renal interstitial fibroblasts (NRK-49F).

Methods: NRK-49F cells were induced using transforming growth factor- $\beta 1$ (TGF- $\beta 1$ ) and pretreated with the proteasome inhibitor MG-132. Cell proliferation was measured using 3-(4,5-dimethylthiazol-2-yl)-2,5-diphenyltetrazolium bromide (MTT). The cell cycle and apoptosis were analyzed using flow cytometry. Apoptosis was also analyzed using a DNA ladder. The protein expression of p53, p27, p21, caspase-3, Bcl-2 and Bax was examined using western blots.

Results: The results showed that TGF- $\beta 1(5 \mathrm{ng} / \mathrm{ml})$ can stimulate the proliferation of NRK-49F cells. MG-132 $(0.25-5 \mu \mathrm{M})$ inhibited TGF- $\beta 1$-induced proliferation in a dose-dependent manner through G1-arrest; TGF- $\beta 1$ alone did not induce apoptosis $(3.8 \pm 0.4 \% v s$. $4.7 \pm 1.6 \%$ ). However, pretreatment with MG-132 significantly induced apoptosis in TGF- $\beta 1$-stimulated NRK-49F cells in a dosedependent manner. A typical DNA ladder was also confirmed in these two groups. Western blot analysis showed that MG-132 activated p53, p21, caspase-3 and Bax, and inhibited Bcl-2 in a dose-dependent manner, while p27 expression remained unchanged.

Conclusions: A proteasome inhibitor inhibited proliferation and induced apoptosis in renal interstitial fibroblasts stimulated by TGF- $\beta 1$. The mechanism may relate to the $\mathrm{p} 53$, p21, caspase-3, Bcl-2 and Bax pathways. Our results suggest that a proteasome inhibitor could be a new strategy to treat renal interstitial fibrosis.
\end{abstract}

Key words:

proteasome inhibitor, transforming growth factor- $\beta 1$, renal interstitial fibroblast, proliferation, apoptosis

\begin{abstract}
Abbreviations: CDK - cyclin-dependent kinases, CKI - cyclin dependent kinase inhibitors, ESRD - end stage renal disease, MM - multiple myeloma, RIF - renal interstitial fibrosis,TGF- $\beta 1$ - transforming growth factor- $\beta 1$, UPP - ubiquitin proteasome pathway
\end{abstract}

\section{Introduction}

Renal interstitial fibrosisis is the final manifestation of end stage renal disease (ESRD). The proliferation and activation of renal interstitial fibroblasts play an important role in tubulointerstitial fibrosis [33]. Transforming growth factor- $\beta 1$ (TGF- $\beta 1$ ) is one of the most important mediators of renal tubulointerstitial fibrosis and inhibition of TGF- $\beta 1$ synthesis may lead to new therapeutic treatments in renal interstitial fibrosis $[10,27]$. Our previous studies have found that TGF- $\beta 1$ can significantly induce the proliferation of renal interstitial fibroblasts [32].

The ubiquitin proteasome pathway (UPP) is the major proteolytic pathway in eukaryotic cells and 
plays a critical role in many cellular processes and diseases through the regulation and selective degradation of proteins in cells via a series of enzyme-linked reactions.

Proteasome inhibition has been associated with suppression of proliferation and induction of apoptosis, especially in rapidly proliferating cells. Both in vivo and in vitro studies have proven that a proteasome inhibitor can activate the apoptosis-related proteins p53, p21, p27 and Bax, and inhibit the activation of the survivor factor $\mathrm{NF}-\kappa \mathrm{B}$ by down-regulating ubiquitin-proteasome-mediated degradation of I $\mathrm{KB}$ $[5,12]$. Consistent with a greater requirement for proteasomal function in cancer cells and other rapidly proliferating cells, proteasomal inhibition causes increased cell death in lymphoma cell lines compared to normal lymphoblasts [26]. Furthermore, rapidly proliferating cells, such as embryonic endothelial cells, are extremely sensitive to apoptosis induced by proteasomal inhibition [9].

However, most of these observations have focused on the treatment of cancers, such as multiple myeloma and leukemia, and whether a proteasome inhibitor really has effect on proliferation and apoptosis in renal interstitial fibroblasts is currently unknown. Our study aimed to examine the role and mechanism of MG-132, a specific dipeptide proteasome inhibitor that inhibits $26 \mathrm{~S}$ proteasome activity, on cell proliferation, apoptosis and related proteins and factors in renal interstitial fibroblasts.

\section{Materials and Methods}

\section{Chemicals}

The proteasome inhibitor MG-132 was purchased from Calbiochem Co. Ltd. (USA), dissolved in dimethyl sulfoxide (DMSO) as a $40 \mu \mathrm{M}$ stock solution and stored at $-20^{\circ} \mathrm{C}$. Recombinant human TGF- $\beta 1$ was purchased from R\&D Co. Ltd. (USA). DMEM/ F12 cell culture medium and trypsin-EDTA were purchased from GIBCO Co. Ltd. (USA). The DNA ladder extraction kit was purchased from the Beyotime Institute of Biotechnology (Jiangsu, China). The annexin V/PI kit was purchased from BioVision Co. Ltd. (UK). Mouse anti-human $\beta$-actin monoclonal antibody was bought from Sigma Co. (USA), the rabbit anti-rat p21 and p53 polyclonal antibodies were obtained from Santa Cruz Biotechnology Co. (USA), rabbit anti-rat p27, caspase-3 and Bax polyclonal antibody and rabbit anti-rat Bcl-2 monoclonal antibody were purchased from Cell Signaling Co. (USA), HRP-labeled goat anti-rabbit IgG and goat anti-mouse IgG were obtained from KPL Co. (USA). Enhanced chemiluminescence (ECL) reagent and PVDF membrane were purchased from Millipore Co. (USA), and $30 \%$ polyacrylamide and TEMED were obtained from Bio-Rad Co. (USA).

\section{Methods}

\section{Cell culture}

NRK-49F cells (purchased from ATCC) were cultured in DMEM/F12 medium supplemented with 10\% fetal calf serum (FCS) (PAA, Austria) in a humidified incubator containing $5 \% \mathrm{CO}_{2}$ at $37^{\circ} \mathrm{C}$.

\section{3-(4,5-Dimethylthiazol-2-yl)-2,5-diphenyltetrazolium bromide assays}

Cells plated in 96-well plates $\left(2 \times 10^{4}\right.$ per well $)$ in $200 \mu \mathrm{l}$ of medium were treated with the proteasome inhibitor MG-132 at specific concentrations $(0-5 \mu \mathrm{M})$ with or without TGF- $\beta 1(5 \mathrm{ng} / \mathrm{ml})$. After $24 \mathrm{~h}$, the cells were incubated with an MTT (Promega, USA) mixture for $4 \mathrm{~h}$. The amount of formazan dye was quantified using a spectrophotometric plate reader (Bio-Rad Co, USA) to measure the absorbance at $570 \mathrm{~nm}$.

\section{Flow cytometric cell cycle analysis}

NRK-49F cells were treated with MG-132 at specific concentrations $(0-1 \mu \mathrm{M})$ with or without TGF- $\beta 1$ $(5 \mathrm{ng} / \mathrm{ml})$ for $24 \mathrm{~h}$. The collected cells were then fixed using cold $75 \%$ ethanol at $-4^{\circ} \mathrm{C}$ overnight, washed in PBS and incubated with $50 \mu \mathrm{g} / \mathrm{ml}$ propidium iodide and $5 \mu \mathrm{g} / \mathrm{ml}$ of RNAase at room temperature for $30 \mathrm{~min}$. After being supplemented with propidium iodide at $50 \mathrm{ml} / 1$ and kept in the dark for $10 \mathrm{~min}$, cycle cell analysis was performed using FACSort flow cytometry (provided by the Department of Cell Biology, Shanghai Jiao Tong University, School of Medicine, China). 


\section{Apoptosis detection using annexin $\mathrm{V}$ and propidium iodide staining}

To confirm the results of the morphological analysis and evaluate apoptosis, annexin V-FITC staining and flow cytometry were performed as recommended by the manufacturer (BD Biosciences, San Diego, CA, USA). The samples were analyzed using a flow cytometer after $24 \mathrm{~h}$ of incubation with MG-132 $(0-2.5 \mu \mathrm{M})$ with or without TGF- $\beta 1(5 \mathrm{ng} / \mathrm{ml})$ to determine the percentage of cells with annexin $\mathrm{V}$ + propidium iodide (early apoptosis) or annexin $\mathrm{V}$ + propidium iodide + staining (late apoptosis).

\section{Determination of DNA fragmentation}

The DNA fragmentation analysis was performed as described using DNA ladder kit. NRK-49F cells $(1 \times$ $10^{6}$ ) were harvested after $24 \mathrm{~h}$ of incubation with $2.5 \mu \mathrm{M}$ of MG-132 by centrifugation and lysed in lysis buffer. After centrifugation, the soluble DNA fragments were dissolved in TE and loaded onto a $1.5 \%$ agarose gel and separated at $60 \mathrm{~V}$ for $90 \mathrm{~min}$. The DNA fragments were visualized by transillumination under UV light.

\section{Western blot}

Western blot analysis was performed as described previously [18]. The proteins were extracted, and an equal amount of protein was taken from each group. The samples were mixed with $5 \times$ SDS sample buffer and heated at $100^{\circ} \mathrm{C}$ for $5 \mathrm{~min}$ before loading onto a gel to perform SDS-PAGE electrophoresis. After the proteins were electrotransferred to a PVDF membrane, nonspecific binding to the membrane was blocked. The membranes were incubated overnight at $4^{\circ} \mathrm{C}$ with various primary antibodies against caspase-3, Bcl-2, Bax, p27, p21 and p53. After the membranes were washed, the binding of the primary antibodies to cleaved caspase-3, Bcl-2, Bax, p27, p21 and p53 was followed by incubation with the secondary antibodies for $2 \mathrm{~h}$ at room temperature. The signals were visualized by ECL. An image analysis system was used to analyze the hybrid signal absorbance.

\section{Statistical analysis}

All of the data represent at least 3 independent experiments and are expressed as the mean \pm SD unless oth- erwise indicated. The differences between the groups were determined using an unpaired Student's $t$-test or a one-way ANOVA when multiple comparisons against the control were required, with a value of $p<$ 0.05 considered significant.

\section{Results}

\section{Effect of MG-132 on the proliferation in NRK-49F cells induced by TGF- $\beta 1$}

We have examined the effect of MG-132 on the proliferation of NRK-49F cells induced by TGF- $\beta 1$ using the MTT assay. TGF- $\beta 1(5 \mathrm{ng} / \mathrm{ml})$ stimulated NRK$49 \mathrm{~F}$ proliferation and cellular viability were much higher compared to the control group ( $p<0.05)$, which is consistent with our previous results (Fig. 1) [32]. MG-132 $(0.25-5 \mu \mathrm{M})$ could significantly inhibit the effect of TGF- $\beta 1$ in a dose-dependent manner. This result infers that MG-132 at such concentration can suppress the proliferation of NRK-49F cells induced by TGF- $\beta 1$.

\section{Effect of MG-132 on the cell cycle in NRK-49F cells induced by TGF- $\beta 1$}

To detect the effect of MG-132 on the cell cycle, flow cytometric cell cycle analysis was used. Compared to

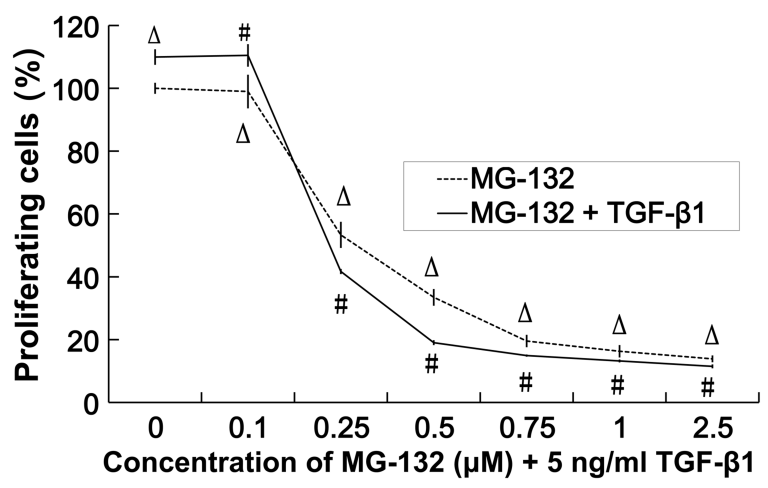

Fig. 1. MG-132 inhibited the proliferation of NRK-49F cells induced by TGF- $\beta 1$ using the MTT method. NRK-49F cells were treated with MG-132 at specific concentrations $(0-5 \mu \mathrm{M})$ with or without TGF- $\beta 1$ $(5 \mathrm{ng} / \mathrm{ml}$ ) for $24 \mathrm{~h}$. Five samples were used for each group, and the experiments were repeated 3 times. Data from 3 independent experiments are shown as the mean \pm SD.MG-132 $(0.25-5 \mu \mathrm{M})$ inhibited TGF- $\beta 1$-inducedproliferation in a dose-dependent manner. $\Delta p<0.05$ vs. control, \# $\mathrm{p}<0.01$ vs. $5 \mathrm{ng} / \mathrm{ml}$ TGF- $\beta 1$ 
Tab. 1. Cell cycle analysis of the effect of MG-132's on TGF- $\beta 1$-stimulated NRK-49F cells ( $\bar{x} \pm s)$

\begin{tabular}{cccc}
\hline Group & S $(\%)$ & G1 $(\%)$ & G2-M $(\%)$ \\
\hline Control & $21.100 \pm 2.941$ & $75.150 \pm 1.135$ & $3.750 \pm 1.923$ \\
$5 \mathrm{ng} / \mathrm{ml}$ TGF- $\beta 1$ & $31.215 \pm 1.633^{\$}$ & $62.835 \pm 2.001^{\$}$ & $5.955 \pm 0.375^{\Delta}$ \\
TGF- $\beta 1+0.10 \mu \mathrm{M} \mathrm{MG-132}$ & $16.637 \pm 1.640^{\# \$}$ & $78.867 \pm 2.232^{\# \$}$ & $4.500 \pm 0.692$ \\
TGF- $\beta 1+0.25 \mu \mathrm{M} \mathrm{MG-132}$ & $9.567 \pm 1.337^{\# \$}$ & $84.747 \pm 1.801^{\# \$}$ & $5.690 \pm 0.510^{\Delta}$ \\
TGF- $\beta 1+0.50 \mu \mathrm{M}$ MG-132 & $8.307 \pm 0.535^{\# \$}$ & $84.447 \pm 0.475^{\# \$}$ & $7.250 \pm 0.990^{\$}$ \\
TGF- $\beta 1+0.75 \mu \mathrm{M} \mathrm{MG-132}$ & $8.067 \pm 2.081^{\# \$}$ & $85.097 \pm 0.982^{\# \$}$ & $6.837 \pm 1.227^{\$}$ \\
TGF- $\beta 1+1.00 \mu \mathrm{M} \mathrm{MG-132}$ & $7.383 \pm 1.440^{\# \$}$ & $85.890 \pm 2.345^{\# \$}$ & $6.730 \pm 0.908^{\$}$ \\
\hline
\end{tabular}

${ }^{\Delta} \mathrm{p}<0.05$ vs. control, ${ }^{\Phi} \mathrm{p}<0.01$ vs. control, ${ }^{\#} \mathrm{p}<0.01$ vs. 5 ng/ml TGF- $\beta 1$
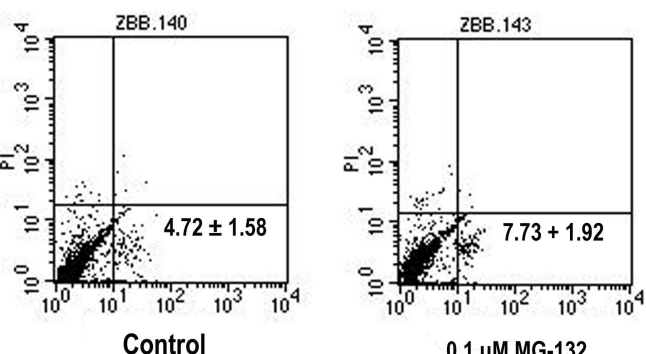

$0.1 \mu \mathrm{M}$ MG-132

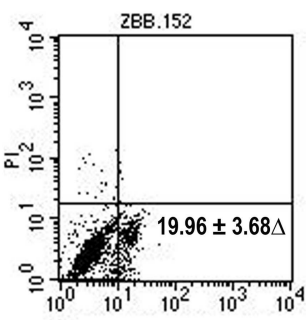

$0.75 \mu$ M MG-132
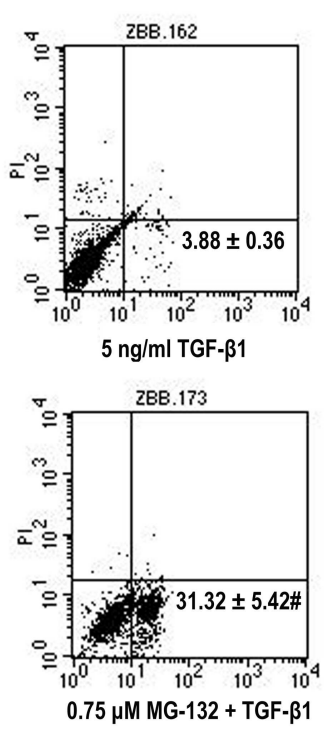
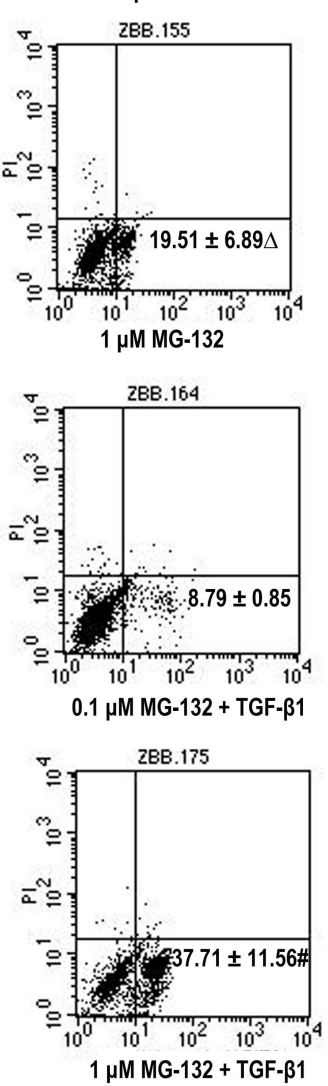
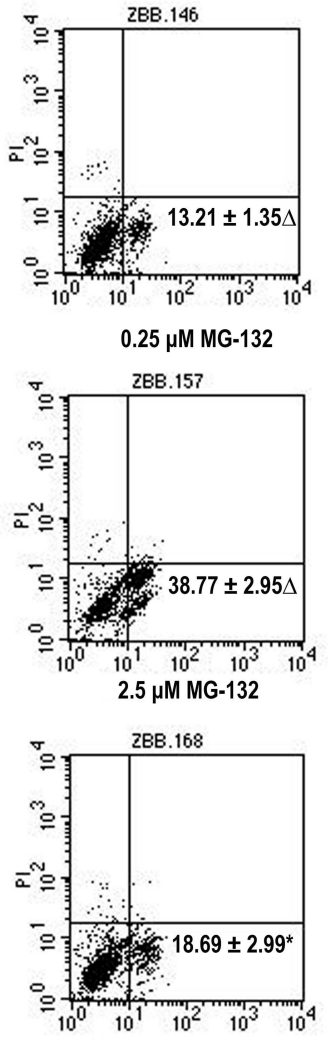

$0.25 \mu M$ MG-132 + TGF- $\beta 1$

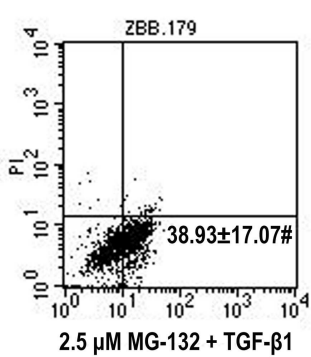

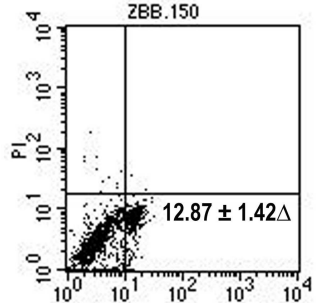

$0.5 \mu \mathrm{M}$ MG-132

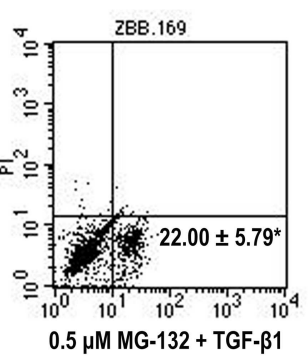

$0.5 \mu M$ MG-132 + TGF- $\beta 1$

Fig. 2. Effect of MG-132 on the cellular apoptosis ratios in NRK-49F cells induced by TGF- $\beta 1$ assessed using annexin V/PI staining. NRK-49F cells were treated with MG-132 at specific concentrations $(0-2.5 \mu \mathrm{M})$ with or without TGF- $\beta 1$ ( $5 \mathrm{ng} / \mathrm{ml})$ for $24 \mathrm{~h}$. Data from 3 independent experiments are shown as the mean \pm SD. $\Delta \mathrm{p}<0.05 \mathrm{vs}$. control, ${ }^{*} \mathrm{p}<0.05 \mathrm{vs} .5 \mathrm{ng} / \mathrm{ml} \mathrm{TGF}-\beta 1$, \# $\mathrm{p}<0.01 \mathrm{vs} .5 \mathrm{ng} / \mathrm{ml}$ TGF- $\beta 1$ 


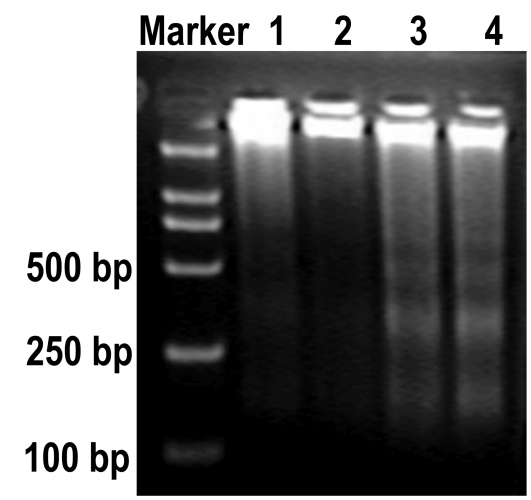

Fig. 3. MG-132 induced apoptosis in NRK-49F cells induced by TGF- $\beta 1$. A typical DNA ladder in NRK-49F cells was observed after being treated with $2.5 \mu \mathrm{M} \mathrm{MG}-132$ with or without $5 \mathrm{ng} / \mathrm{ml} \mathrm{TGF-} \beta 1$ for $24 \mathrm{~h}$. Lanes: 1) control group; 2) $5 \mathrm{ng} / \mathrm{ml}$ TGF- $\beta 1$; 3) 2.5 MM MG-132; 4) $2.5 \mu \mathrm{M} \mathrm{MG}-132+5 \mathrm{ng} / \mathrm{ml}$ TGF- $\beta 1$

the control group, $24 \mathrm{~h}$ after TGF- $\beta 1$ (5 ng/ml) stimulation, the percentage of $\mathrm{S}$ phase cells clearly increased $(31.2 \pm 1.6$ vs. $21.1 \pm 2.9 \% \mathrm{p}<0.05)$, and the percentage of G2/S and G1 phase cells decreased significantly $(\mathrm{p}<0.05)$. After being supplemented with MG-132 $(0,0.1,0.25,0.5,0.75$ or $1 \mu \mathrm{M})$, the percentage of S phase cells dramatically decreased in a dosedependent manner $(31.2,16.6,9.6,8.3,8.1$ and $7.4 \%$, respectively) and the percentage of G1 phase increased. This result suggests that MG-132 can inhibit the G1 phase transition of the cell cycle in NRK-49F cells induced by TGF- $\beta 1$ (Tab. 1).

\section{Effect of MG-132 on the cellular apoptosis ratios in NRK-49F cells induced by TGF- $\beta 1$}

After $24 \mathrm{~h}$, TGF- $\beta 1$ alone could not induce apoptosis $(3.8 \pm 0.4$ vs. $4.7 \pm 1.6 \%)$, while pretreatment with MG-132 $(0,0.1,0.25,0.5,0.75,1$ or $2.5 \mu \mathrm{M})$ significantly induced apoptosis in TGF- $\beta 1$-stimulated NRK-49F cells in a dose-dependent manner (Fig. 2).

\section{Effect of MG-132 on apoptosis in NRK-49F cells induced by TGF- $\beta 1$}

Twenty-four hours after the NRK-49F cells were treated with $2.5 \mu \mathrm{M}$ of MG-132 with or without $5 \mathrm{ng} / \mathrm{ml}$ TGF- $\beta 1$, the typical DNA ladder was observed, while the control and TGF- $\beta 1$ alone groups had no such ladder (Fig. 3).
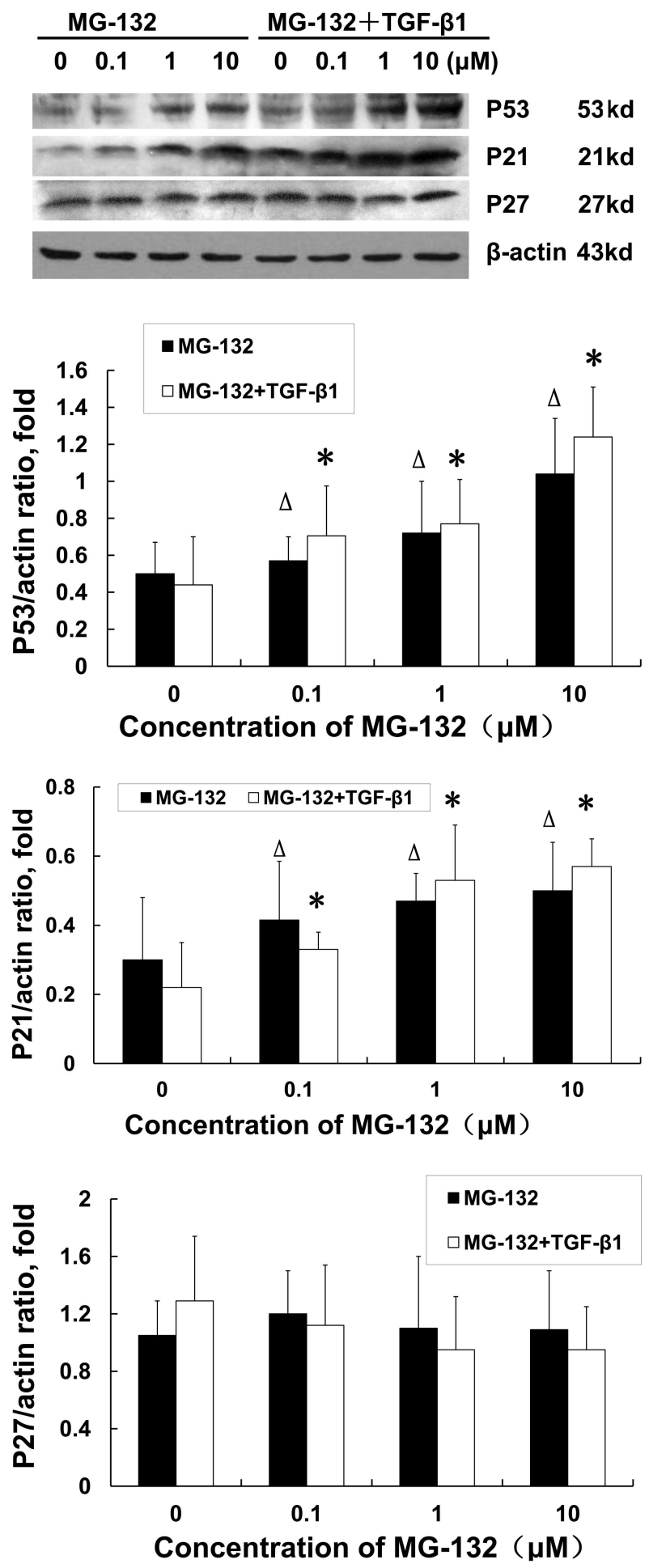

Fig. 4. The effect of MG-132 on p21, p27 and p53 protein expression in NRK-49F cells induced by TGF- $\beta 1$. NRK-49F cells were treated with a specific concentration of MG-132 $(0-10 \mu \mathrm{M})$ in the presence or absence of TGF- $\beta 1(5 \mathrm{ng} / \mathrm{ml})$ for $24 \mathrm{~h}$. The western blots were repeated 3 times. MG-132 induced p21 and p53 in a dose-dependent manner, while p27 expression remained unchanged. $\Delta p<0.05$, ${ }^{*} p<$ 0.05 vs. $5 \mathrm{ng} / \mathrm{ml}$ TGF- $\beta 1$ 

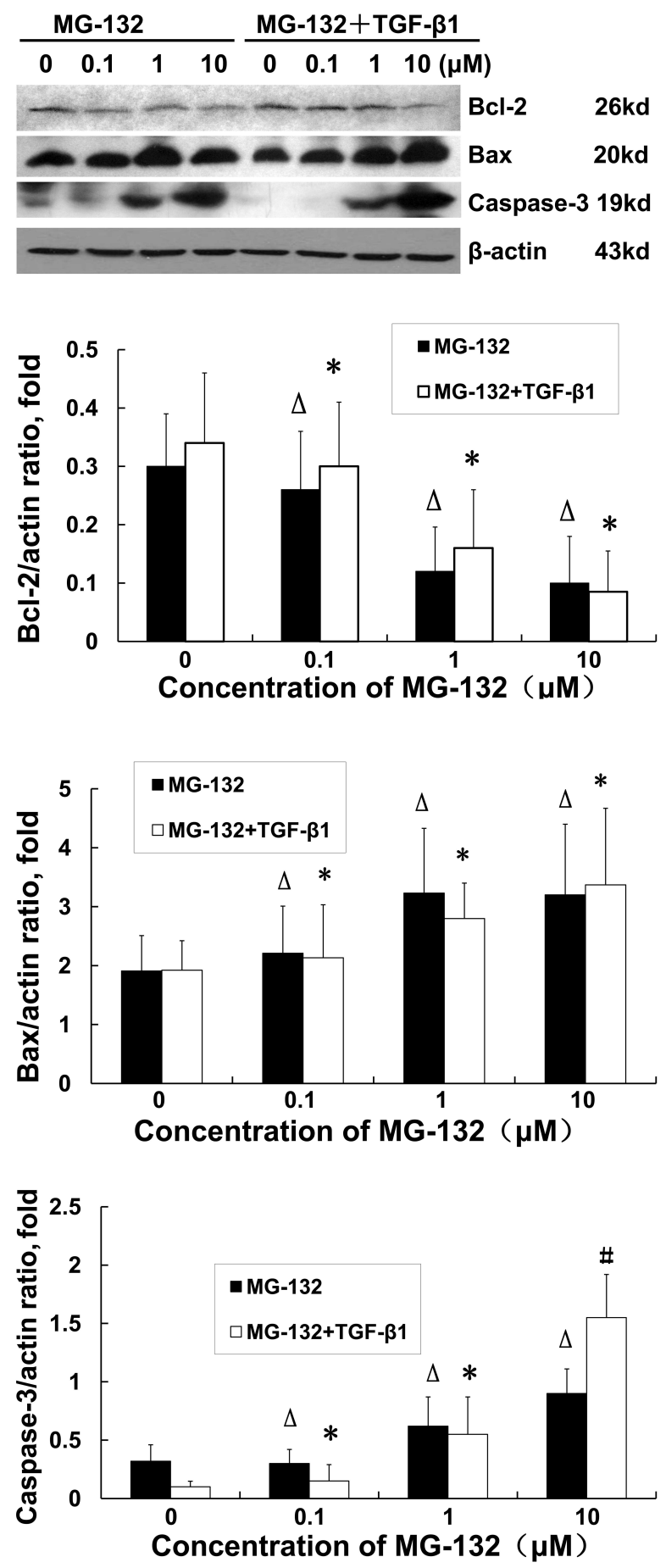

Fig. 5. The effect of MG-132 on Bcl-2, Bax and caspase-3 protein expression in NRK-49F cells induced by TGF- $\beta 1$. NRK-49F cells were treated with specific concentrations of MG-132 $(0-10 \mu \mathrm{M})$ in the presence or absence of TGF- $\beta 1$ ( $5 \mathrm{ng} / \mathrm{ml}$ ) for $24 \mathrm{~h}$. The western blots were repeated 3 times. MG-132 activated caspase- 3 and Bax and inhibited Bcl-2 in a dose-dependent manner. $\Delta p<0.05$ vs. control, ${ }^{*} p<$ 0.05 vs. $5 \mathrm{ng} / \mathrm{ml} \mathrm{TGF-} \beta 1$, \# $\mathrm{p}<0.01$ vs. $5 \mathrm{ng} / \mathrm{ml} \mathrm{TGF-} \beta 1$

\section{Effects of MG-132 on p53, p21 and p27 protein expression in NRK-49F cells}

We treated NRK-49F cells with specific concentrations $(0-10 \mu \mathrm{M})$ of MG-132 for $24 \mathrm{~h}$ and analyzed them using immunoblotting. Treatment with MG-132 led to a marked increase in the level of p53 in NRK-49F cells stimulated by TGF- $\beta 1$ in a dosedependent manner (Fig. 4). MG-132 treatment could also up-regulate the expression of $\mathrm{p} 21$, a cyclindependent kinase inhibitor known to induce growth arrest by inhibiting cyclin-dependent kinases, which could promote progression through the cell cycle. However, p27 expression remained unchanged.

\section{Effects of MG-132 on Bcl-2, Bax and caspase-3 protein expression in NRK-49F cells}

To determine whether MG-132 could induce apoptosis in NRK-49F cells via the down-regulation of $\mathrm{Bcl}-2$, caspase-3 and Bax, known targets of the ubiquitinproteasome pathway, we examined their expression using western blot analysis. Significant Bcl-2 expression was detected in NRK-49F cells, which was down-regulated by treatment with MG-132 in a dosedependent manner after $24 \mathrm{~h}$, while Bax and caspase-3 protein expression were up-regulated (Fig. 5).

\section{Discussion}

Renal interstitial fibrosis (RIF) is the final common pathway of end stage renal disease (ESRD), and the correlation of renal tubulointerstitial fibrosis with renal function is much closer than with glomerulosclerosis [16]. The proliferation and activation of fibroblasts is generally considered to play a pivotal role in fibrogenesis [33].

The ubiquitin-proteasome system is responsible for the degradation of intracellular proteins. In this process, proteins targeted for degradation are tagged by multimers of an evolutionarily conserved protein, known as ubiquitin, and are degraded by the $26 \mathrm{~S}$ proteasome, a large multiprotein complex. Rapid and irreversible proteasomal protein degradation is pivotal to the regulation of many cellular processes, including cellular proliferation and apoptosis. Inhibition of the proteasome leads to an inappropriate accumulation of a large number of proteins, which leads to conflicting 
cellular signals and cell death, and the anti-tumor effects of a proteasome inhibitor have been extensively studied in multiple myeloma (MM) cells and other cancer cells [1, 3, 4, 14, 15, 23-25]. A proteasome inhibitor can inhibit the growth and proliferation of cancer cells and activate apoptosis [20].

MG-132 is one of the most important proteasome inhibitors. MG-132 is the specific inhibitor of the ubiquitin proteasome pathway (UPP) and can reversely inhibit the activity of proteasomal chymotrypsin-like enzyme and inhibit the action of kathepsin and calpains. Recent studies have suggested that MG-132 can effectively inhibit the growth of digestive tumor cells and leukemia cells and induce apoptosis in cancer cells. As a result, MG-132 is considered to be a potential anti-tumor drug $[8,11,22,30]$. However, the anti-renal interstitial fibrosis effects of this proteasome inhibitor have rarely been reported $[28,29]$.

In our study, TGF- $\beta 1$ was used to stimulate NRK$49 \mathrm{~F}$ cells, and the percentage of proliferation is $110 \%$ compared to the control group, which means that TGF- $\beta 1(5 \mathrm{ng} / \mathrm{ml})$ can induce NRK-49F proliferation within $24 \mathrm{~h}$. We have found that MG-132 can dramatically inhibit the proliferation of NRK-49F cells induced by TGF- $\beta 1$ in a dose-dependent manner. The analysis of the cell cycle shows that MG-132 can dose dependently increase the percentage of G1 phase NRK-49F cells induced by TGF- $\beta 1$ and decrease the percentage of cells in $\mathrm{S}$ phase. As a result, the cells are prevented from entering the mitotic phase.

The analysis for apoptosis demonstrates that TGF- $\beta 1(5 \mathrm{ng} / \mathrm{ml})$ alone cannot induce apoptosis in NRK-49F cells, but MG-132 pretreatment can promote cell apoptosis in a dose-dependent manner, and the DNA ladder results also confirm the pro-apoptotic effect of MG-132. We have found that TGF- $\beta 1$ alone cannot affect Bcl-2 and Bax expression and can slightly down-regulate the expression of $\mathrm{p} 21$ and active fragments of caspase-3. Treatment with MG-132 led to up-regulation of p53, p21, caspase-3 and Bax expression and down-regulation of $\mathrm{Bcl}-2$ protein expression, which is known to induce growth arrest and apoptosis. However, p27 expression remained unchanged. These results infer that MG-132, an ubiquitin proteasome inhibitor, may induce apoptosis and inhibit the proliferation of NRK-49F cells induced by TGF- $\beta 1$, and these effects may be performed by activating p53 and caspase-3 and up-regulating $\mathrm{Bax} /$ Bcl-2. Furthermore, p21 may affect the MG-132- mediated inhibition of NRK-49F cell proliferation by halting the G1 phase transition.

Also, p53 has been established to play a key role in apoptosis and is a substrate of UPP. Consequently, p53 has been considered to be the first candidate factor to link UPP with apoptosis. Moreover, p53 acts as a transcription factor and mediates its effect by modulating the expression of its downstream target genes [19]. Some of these genes encode proteins that control the integrity and permeability of mitochondria, such as the proteins of the Bcl-2 family (Bax, Bcl-2, Bcl$\mathrm{Xl}$, FAS, DR5 and DcR1/TRID). Another important protein, p21, can, in low concentrations, function as an activator of the cyclin dependent kinases (CDK) to promote cell-cycle progression. A high concentration of p21, however, can inhibit kinase activity to halt cell-cycle progression and decrease cell growth [31]. In a breast cancer study, Maclaren et al. have found that MG-132 treatment can induce apoptosis in KIM-2 cells in a p53-dependent manner [19].

P21 and p27, as widespread cyclin-dependent kinase inhibitors (CKI), are important inhibitors that participate in regulating $\mathrm{G} 1$ phase transition, and $\mathrm{p} 21$ regulation by $\mathrm{p} 53$ mainly takes place at the transcriptional level. P21 can also be degraded by ubiquitinylation. The regulation of p27 is at the protein level, and p27 is degraded by the ubiquitin proteasome pathway, in which Skp2 is a rate-limiting component. Thus, a proteasome inhibitor can block the degradation of p21 and p27 and result in the accumulation of these proteins, consequently halting the cell cycle $[7,17]$.

Proteins from the caspase and $\mathrm{Bcl}-2$ families are central regulators of apoptosis. Hideshima et al. has reported that bortezomib, another important proteasome inhibitor, induced apoptosis in multiple myeloma cells by activating JNK, followed by caspase-3 activation [13]. Bax could be degraded by ubiquitinproteasome pathway directly. The Bcl-2 family is also known to be a target of p53 and inhibition of the ubiquitin-proteasome pathway can induce the protein degradation of Bcl-2 in many cell lines. However, the mechanism by which the Bcl-2 family affects the ubiquitin-proteasome pathway still remains unknown. The Bcl-2 protein family plays a central role in regulating apoptosis [6], and within this family, Baz, Bak, $\mathrm{Bcl}-\mathrm{Xs}$ and $\mathrm{Bad}$ have proapoptotic activity, while $\mathrm{Bcl}-2, \mathrm{Bcl}-\mathrm{X} 1$, and Bcl-w have anti-apoptotic activity. Regulation of the proapoptotic/ anti-apoptotic ratio is crucial. The proapoptotic effect of a proteasome inhibitor has a close relationship with the Bcl-2 family 
$[1,2,21]$, and Bid, Bax, Bak, Bik and Bim can be directly degraded by UPP. Bcl-2 can be regulated in a transcriptional and posttranscriptional manner; p53 can positively regulate $\mathrm{Bax}$ and negatively regulate Bcl-2. The mechanism by which the Bcl-2 family affects the ubiquitin-proteasome pathway still remains unknown. However, inhibiting the ubiquitin pathway can result in the specific degradation of all kinds of Bcl-2 proteins by caspase-3, which infers that the ubiquitin pathway regulates Bcl-2 by some unknown mechanism.

In summary, the present results indicate that treatment with MG-132 potentiates apoptosis and inhibits proliferation in NRK-49F cells stimulated with TGF- $\beta 1$. Our findings seem to indicate that this response may be due to the activation of p53, p21 and caspase-3, and the up-regulation of $\mathrm{Bax} / \mathrm{Bcl}-2$. These signal pathways can affect each other through cross-talk. Our results suggest that a proteasome inhibitor could be a new strategy to treat renal interstitial fibrosis.

\section{Competing interests:}

The authors have declared no competing interests.

\section{Acknowledgment:}

Financial support: This study was supported by grants from the National Nature Science Foundation of China (30270613 and 30771000) and the Shanghai Science and Technology Commission of Shanghai Municipality (08dz1900502) China.

\section{References:}

1. Bae SH, Ryoo HM, Kim MK, Lee KH, Sin JI, Hyun MS: Effects of the proteasome inhibitor bortezomib alone and in combination with chemotherapeutic agents in gastric cancer cell lines. Oncol Rep, 2008, 19, 1027-1032.

2. Breitschopf K, Zeiher AM, Dimmeler S: Ubiquitinmediated degradation of the proapoptotic active form of bid. A functional consequence on apoptosis induction. J Biol Chem, 2000, 275, 21648-21652.

3. Bross PF, Kane R, Farrell AT, Abraham S, Benson K, Brower M. E, Bradley sincerely et al.: Approval summary for bortezomib for injection in the treatment of multiple myeloma. Clin Cancer Res, 2004, 10, 3954-3964.

4. Chari A, Mazumder A, Jagannath S: Proteasome inhibition and its therapeutic potential in multiple myeloma. Biologics, 2010, 4, 273-287.

5. Chen D, Frezza M, Schmitt S, Kanwar JP. Dou Q: Bortezomib as the first proteasome inhibitor anticancer drug: current status and future perspectives. Curr Cancer Drug Targets, 2011, 11, 239-253.
6. Cory S, Huang DC, Adams JM: The Bcl-2 family: roles in cell survival and oncogenesis. Oncogene, 2003, 22, 8590-8607.

7. Cusack JC Jr, Liu R, Houston M, Abendroth K, Elliott PJ, Adams J, Baldwin AS, Jr: Enhanced chemosensitivity to CPT-11 with proteasome inhibitor PS-341: implications for systemic nuclear factor- $\mathrm{kB}$ inhibition. Cancer Res, 2001, 61, 3535-3540.

8. Ding WX, Ni HM, Chen X, Yu J, Zhang L, Yin XM: A coordinated action of Bax, PUMA, and $\mathrm{p} 53$ promotes MG132-induced mitochondria activation and apoptosis in colon cancer cells. Mol Cancer Ther, 2007, 6, 1062-1069.

9. Drexler HC, Risau W, Konerding MA: Inhibition of proteasome function induces programmed cell death in proliferating endothelial cells. FASEB J, 2000, 14, 65-77.

10. Du J, Wang L, Liu L, Fan Q, Yao L, Cui Y, Kang P et al.: IFN- $\gamma$ suppresses the high glucose-induced increase in TGF- $\beta 1$ and CTGF synthesis in mesangial cells. Pharmacol Rep, 2011, 63, 1137-1144.

11. He Q, Huang Y, Sheikh MS: Proteasome inhibitor MG132 upregulates death receptor 5 and cooperates with Apo2L/TRAIL to induce apoptosis in Bax-proficient and -deficient cells. Oncogene, 2004, 23, 2554-2558.

12. Hideshima T, Chauhan D, Richardson P, Mitsiades C, Mitsiades N, Hayashi T, Munshi N et al.: NF- $\kappa$ B as a therapeutic target in multiple myeloma. J Biol Chem, 2002, 277, 16639-16647.

13. Hideshima T, Mitsiades C, Akiyama M, Hayashi T, Chauhan D, Richardson P, Schlossman R et al.: Molecular mechanisms mediating antimyeloma activity of proteasome inhibitor PS-341. Blood, 2003, 101, 1530-1534.

14. Jagannath S, Barlogie B, Berenson J, Siegel D, Irwin D, Richardson PG, Niesvizky R et al.: A phase 2 study of two doses of bortezomib in relapsed or refractory myeloma. Br J Haematol, 2004, 127, 165-172.

15. Jones MD, Liu JC, Barthel TK, Hussain S, Lovria E, Cheng D, Schoonmaker JA et al.: A proteasome inhibitor, bortezomib, inhibits breast cancer growth and reduces osteolysis by downregulating metastatic genes. Clin Cancer Res, 2010, 16, 4978-4989.

16. Klahr S, Morrissey J, Hruska K, Wang S, Chen Q: New approaches to delay the progression of chronic renal failure. Kidney Int, 2002, Suppl, 23-26.

17. Lashinger LM, Zhu K, Williams SA, Shrader M, Dinney CP, McConkey DJ.: Bortezomib abolishes tumor necrosis factor-related apoptosis-inducing ligand resistance via a p21-dependent mechanism in human bladder and prostate cancer cells. Cancer Res, 2005, 65, 4902-4908.

18. Liu L, Eby MT, Rathore N, Sinha SK, Kumar A, Chaudhary PM: The human herpes virus 8-encoded viral FLICE inhibitory protein physically associates with and persistently activates the IKB kinase complex. J Biol Chem, 2002, 277, 13745-13751.

19. MacLaren AP, Chapman RS, Wyllie AH, Watson CJ: p53-dependent apoptosis induced by proteasome inhibition in mammary epithelial cells. Cell Death Differ, 2001, 8, 210-218.

20. Nalepa G, Rolfe M, Harper JW: Drug discovery in the ubiquitin-proteasome system. Nat Rev Drug Discov, 2006, 5, 596-613. 
21. Nikrad M, Johnson T, Puthalalath H, Coultas L, Adams J, Kraft AS.: The proteasome inhibitor bortezomib sensitizes cells to killing by death receptor ligand TRAIL via BH3-only proteins Bik and Bim. Mol Cancer Ther, 2005, 4, 443-449.

22. Pandit B, Gartel AL: Proteasome inhibitors induce p53independent apoptosis in human cancer cells. Am J Pathol, 2011, 178, 355-360.

23. 23. Richardson PG, Mitsiades C: Bortezomib: proteasome inhibition as an effective anticancer therapy. Future Oncol, 2005, 1, 161-171.

24. Richardson PG, Mitsiades C, Hideshima T, Anderson KC: Bortezomib: proteasome inhibition as an effective anticancer therapy. Annu Rev Med, 2006, 57, 33-47.

25. Richardson PG, Sonneveld P, Schuster MW, Irwin D, Stadtmauer EA, Facon T, Harousseau JL et al.: Bortezomib or high-dose dexamethasone for relapsed multiple myeloma. N Engl J Med, 2005, 352, 2487-2498.

26. Soligo D, Servida F, Delia D, Fontanella E, Lamorte G, Caneva L, Fumiatti R, Lambertenghi Deliliers G: The apoptogenic response of human myeloid leukaemia cell lines and of normal and malignant haematopoietic progenitor cells to the proteasome inhibitor PSI. Br J Haematol , 2001, 113, 126-135.

27. Strutz F, Zeisberg M, Renziehausen A, Raschke B, Becker V, Van Kooten C, Muller G: TGF- $\beta 1$ induces proliferation in human renal fibroblasts via induction of basic fibroblast growth factor (FGF-2). Kidney Int, 2001, 59, 579-592.
28. Tan R, Zhang J, Tan X, Zhang X, Yang J, Liu Y: Downregulation of SnoN expression in obstructive nephropathy is mediated by an enhanced ubiquitin-dependent degradation. J Am Soc Nephrol, 2006, 17, 2781-2791.

29. Tashiro K, Tamada S, Kuwabara N, Komiya T, Takekida $\mathrm{K}$, Asai T, Iwao $\mathrm{H}$ et al.: Attenuation of renal fibrosis by proteasome inhibition in rat obstructive nephropathy: possible role of nuclear factor kappaB. Int J Mol Med, 2003, 12, 587-592.

30. Ustundag Y, Bronk SF, Gores GJ: Proteasome inhibition-induces endoplasmic reticulum dysfunction and cell death of human cholangiocarcinoma cells. World J Gastroenterol, 2007, 13, 851-857.

31. Wang W, Nacusi L, Sheaff RJ, Liu X: Ubiquitination of p21Cip1/WAF1 by SCFSkp2: substrate requirement and ubiquitination site selection. Biochemistry, 2005, 44, 14553-14564

32. Wang WM, Liu F, Chen N: Effects of peroxisome proliferators-activated receptor $\gamma$ agonists on transforming growth factor- $\beta 1$ and Smads signal pathway: experiment with rat renal fibroblasts (Chinese). Zhonghua Yi Xue Za Zhi, 2006, 86, 740-744.

33. Zeisberg M, Strutz F, Muller GA: Role of fibroblast activation in inducing interstitial fibrosis. J Nephrol, 2000, 13, Suppl 3, S111-120.

Received: May 14, 2012; in the revised form: February 17, 2013; accepted: April 18, 2013. 